University of Chitral Journal of Botany |UOCHJB|
ISSN: 2616-9150

2017: Vol. 01:Issue No. 01: Page No.144-151

doi: $\underline{\text { https://doi.org/10.33195/uochjb-v1i1412017 }}$

https://jb.uoch.edu.pk/index.php/j1

Research Paper

Open Access

\section{HYPOGLYCEMIC AND HYPOCHOLESTROLEMIC STUDY OF MONOTHICA BOXIFOLIA FALC. IN INDUCED DIABETIC RABBITS}

\author{
TAO SHIHENG ${ }^{*}$, SALMA BIBI ${ }^{2}$, SIDDIQ UR RAHMAN ${ }^{3}$ \\ ${ }^{1}$ Bioinformatics Center, College of Life Sciences, Northwest A \& F University, Yangling, \\ Shaanxi 712100, China \\ ${ }^{2}$ Department of Botany, University of Malakand \\ ${ }^{3}$ Department of Computer Science \& Bioinformatics, Khushal Khan Khattak University, Karak, \\ Pakistan.
}

*Corresponding author: shihengt@nwsuaf.edu.cn

Article Published on: 23 September 2019

Keywords: Glucose, Diabetic mellitus, Alloxan monohydrates, Hyperglycemic, cholesterol 


\section{Introduction:}

Illness in which the body's ability to deliver or react to the hormone insulin is hindered, bringing about unusual digestion of starches and raised dimensions of glucose in the blood. A polygenic ailment portrayed by anomalous high glucose levels in the blood any of a few metabolic issue set apart by extreme pee and tireless thirst. Diabetes mellitus is perceived just like a disorder, a gathering of scatters that have hyperglycaemia and glucose bigotry as their trademark, due either to insulin lack or to the debilitated viability of insulin's activity, or to a mix of these. So as to comprehend diabetes it is important to comprehend the ordinary physiological procedure happening during and after a dinner. Nourishment goes through the stomach related framework, where supplements, including proteins, fat and starches are retained into the circulatory system. The nearness of sugar, a starch, sign to the endocrine pancreas to emit the hormone insulin. Insulin causes the take-up and capacity of sugar by practically all tissue types in the body, particularly the liver, musculature and fat tissues (Roussel,M. 1998). The dynamic idea of the infection requires consistent reassessment of glycaemic control in individuals with diabetes and fitting change of remedial regimens. At the point when glycaemic control is never again kept up with a solitary specialist, the expansion of a moment or third medication is typically more viable than changing to another single agent.Medicinal plants which have demonstrated enemy of diabetic movement during prior examinations incorporate Panax species, Phyllanthus species, Acacia arabica, Aloe vera, Aloe barbadensis, Artemisia pallens, Momordica charantia, Alium cepa, Trigonella foenum-graecum and so on (Vandebroek, 2007). Not many South-African plants have been logically broke down for their enemy of diabetic attributes. The latest work was finished by (Van Huyssteen 2007) and (Van de Venter etal., 2008). A few specialists trust it may be averted at the idle immune system organize, before it begins obliterating beta cells. The present research goes for the extraction,fractionation assurance of hypoglycemic properties of the plant concentrate of Monothica boxifolia (falc). To assess the hypoglycemic action of Monothica boxifolia separate in alloxan initiated diabetic hares. 


\section{Materials and Methods}

Monothica boxifolia (falc) is found all through the precipitous territories of Khyber Pakhtun khwa.its locally accessible and plant is utilized mouth wash and improve digestion.no insect diabetic examination has yet been directed on this plant, therefore, the said plant has been chosen. Monothica boxifolia (falc) was gathered from Ibrahim khail, Tehsil: batkhela, District malakand The dried leaves and organic products (without seeds) of plants were crushed with processor. Oryctolagus cuniculus were chosen as exploratory creature. An aggregate of 120 bunnies were acquired from nearby market. Every one of the hares were moved to Bio Park of University of Malakand for acclimatization.

Gathering no-1: Rabbits having body weight of $1300 \mathrm{~g}$.

Gathering no-2: Rabbits having body weight of $1200 \mathrm{~g}$.

Gathering no-3: Rabbits having body weight of $1250 \mathrm{~g}$.

Gathering no-4: Rabbits having body weight of $1300 \mathrm{~g}$.

Gathering no-5: Rabbits having body weight of $1400 \mathrm{~g}$.

Diabetus was induced with Alloxane monohydrate. Prior to the commencement of prescription, the blood tests were gathered haphazardly from every one of the gatherings. Blood tests were kept in chilly condition for the confinement of serum. Serum overflowed out and were examined through Blood Chemistry Analyzer (1400) Italy. Glucose and ALP levels were examined.

\section{Drug Administration:}

Gathering A was kept as unmedicated control having Diabetes mellitus.

Gathering B was treated with Glucophage (Metformin $\mathrm{HCl}$ ) at the dose rate of $10 \mathrm{mg} / \mathrm{kg}$ body weight.

Gathering $\mathrm{C}$ was treated with plant separate at the dose rate of $100 \mathrm{mg} / \mathrm{kg}$ body weight.

Gathering D was treated with plant separate at the dose rate of $200 \mathrm{mg} / \mathrm{kg}$ body weight.

Gathering E was treated with plant extricate at the dose rate of $300 \mathrm{mg} / \mathrm{kg}$ body weight. 


\section{Collection of blood tests:}

Blood tests were gathered from every one of the gatherings with following calendar, Zero, 2, 4, $6,8,10$ hours. Blood tests were gathered from every single gathering and were examined. Serum was gathered in bird of prey tubes and was centrifugated at 4000rpm for 8 minutes and was dissected by Blood Chemistry Analyser (1400) Italy and scheedzu Double Beam UV Spectro Photometer (Japan) for various biochemical parameters.

\section{Biochemical Analysis of Glucose:}

The protocol of Barham and Trinder, 1972 was used for analysis of glucose.

Cholesterol determination: The protocol of Tietz, 1965 was utilized for the study ofcholesterol.

\section{Results}

Table 1 showing Blood glucose (mg/dl) level of rabbits in triplicates

\begin{tabular}{|l|c|c|c|c|c|}
\hline Treatments & 2 hour & $\mathbf{4}$ hour & $\mathbf{6}$ hour & $\mathbf{8}$ hour & $\mathbf{1 0}$ hour \\
\hline Untreated control & 90.00 & 93.00 & 92.0 & 90.00 & 92.00 \\
\hline Diabetic control + Glucopage (10mg/kg) & & & & & \\
\hline $\begin{array}{l}\text { Diabetic + Methanolic extract of Plant } \\
100 \mathrm{mg} / \mathrm{kg}\end{array}$ & 399.00 & 301.00 & 288.00 & 207.00 & 161.00 \\
\hline $\begin{array}{l}\text { Diabetic + Methanolic extract of Plant } \\
\text { 200mg/kg }\end{array}$ & 341.00 & 322.00 & 302.00 & 283.00 & 271.00 \\
\hline $\begin{array}{l}\text { Diabetic + Methanolic extract of Plant } \\
300 \mathrm{mg} / \mathrm{kg}\end{array}$ & 301.00 & 291.00 & 272.00 & 261.00 & 255.00 \\
\hline
\end{tabular}


Table 2 showing blood cholesterol $(\mathrm{mg} / \mathrm{dl}$ ) level of rabbits in triplicate

\begin{tabular}{|l|c|c|c|c|c|}
\hline Treatments & $\mathbf{2}$ hour & $\mathbf{4}$ hour & $\mathbf{6}$ hour & $\mathbf{8}$ hour & $\mathbf{1 0}$ hour \\
\hline Untreated control & 105.00 & 106.00 & 104.0 & 100.00 & 102.00 \\
\hline $\begin{array}{l}\text { Diabetic control + } \\
\text { Glucopage (10mg/kg) }\end{array}$ & 219.00 & 211.00 & 218.00 & 217.00 & 261.00 \\
\hline $\begin{array}{l}\text { Diabetic + Methanolic } \\
\text { extract of Plant 100mg/kg }\end{array}$ & 191.00 & 182.00 & 182.00 & 183.00 & 171.00 \\
\hline $\begin{array}{l}\text { Diabetic + Methanolic } \\
\text { extract of Plant 200mg/kg }\end{array}$ & 151.00 & 141.00 & 132.00 & 131.00 & 135.00 \\
\hline $\begin{array}{l}\text { Diabetic + Methanolic } \\
\text { extract of Plant 300mg/kg }\end{array}$ & & & & & \\
& 156.00 & 131.00 & 133.00 & 133.00 & 121.00 \\
\hline
\end{tabular}

Effect of Monothica Boxifolia (falc) extract on blood glucose level in induced diabetic rabbits in triplicate

The table show the impacts of Monothica Boxifolia (falc) concentrate of glucose dimension of diabetic hares with deference of ordinary control and diabetics control. The impact of various dosages of ethanol concentrate of Monothica boxifolia (falc) on the fasting blood glucose level in diabetic Rabbits is given in Table 4.1. The fasting blood glucose dimensions of diabetic control bunnies were essentially higher than those of typical control hares on hours $2,4,6,8,10$. In diabetic bunnies, treated with $100 \mathrm{mg} / \mathrm{kg}, 200 \mathrm{mg} / \mathrm{Kg}$ and $300 \mathrm{mg} / \mathrm{Kg}$ methanolic concentrate and Glucopage $(10 \mathrm{mg} / \mathrm{kg})$, fasting blood glucose level essentially brought down from 2, 4,6,8 and 10 hours of treatment as contrasted and diabetic control hares, individually. Created decrease of on 
fasting blood glucose dimension of diabetic hares on hour 2,4,6,8, and 10, individually. 271.00 on hour 10 which was essentially fall in fasting blood glucose level.

\section{Blood cholesterol level in induced diabetic rabbits triplicate}

The table exhibit the impact of Monothica boxifolia concentrate of blood cholesterol dimension of diabetic bunnies with deference of normol control and diabetic control the impact of various dosages of ethanol concentrate of Monothica boxifolia (falc) on the blood cholesterol level in diabetic hares are given in table 2 .the diabetics hares treated with $100 \mathrm{mg} / \mathrm{kg}, 200 \mathrm{mg} / \mathrm{kg}$, $300 \mathrm{mg} / \mathrm{kg}$, methonolic extricate and Glucophage $(10 \mathrm{mg} / \mathrm{kg})$, fundamentally impact on blood cholesterol level from 2,4,6, and 10 hours of treatment is contrast and diabetics control hares , separately .furthermore $100 \mathrm{mg} / \mathrm{kg}$ portion impact blood cholesterol level blood cholesterol dimension Of diabetic hares on hours 2,4,6and 10 respectivily.

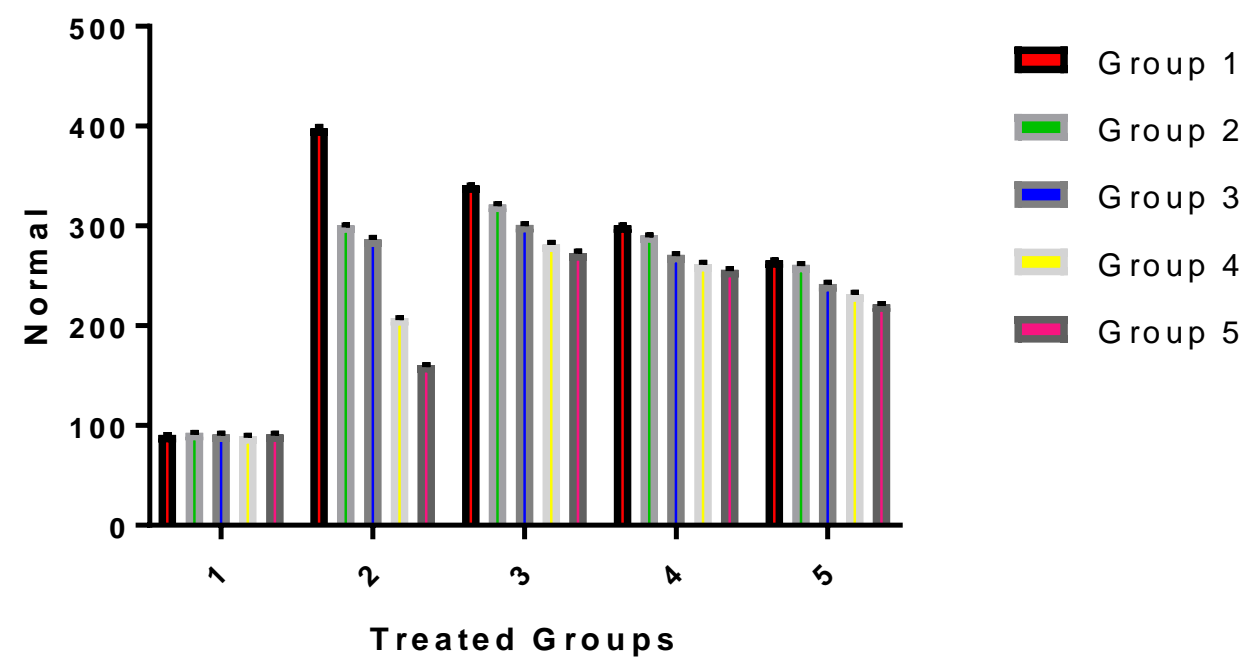

Figure 1: Blood Glucose level in induced diabetic rabbits triplicate 


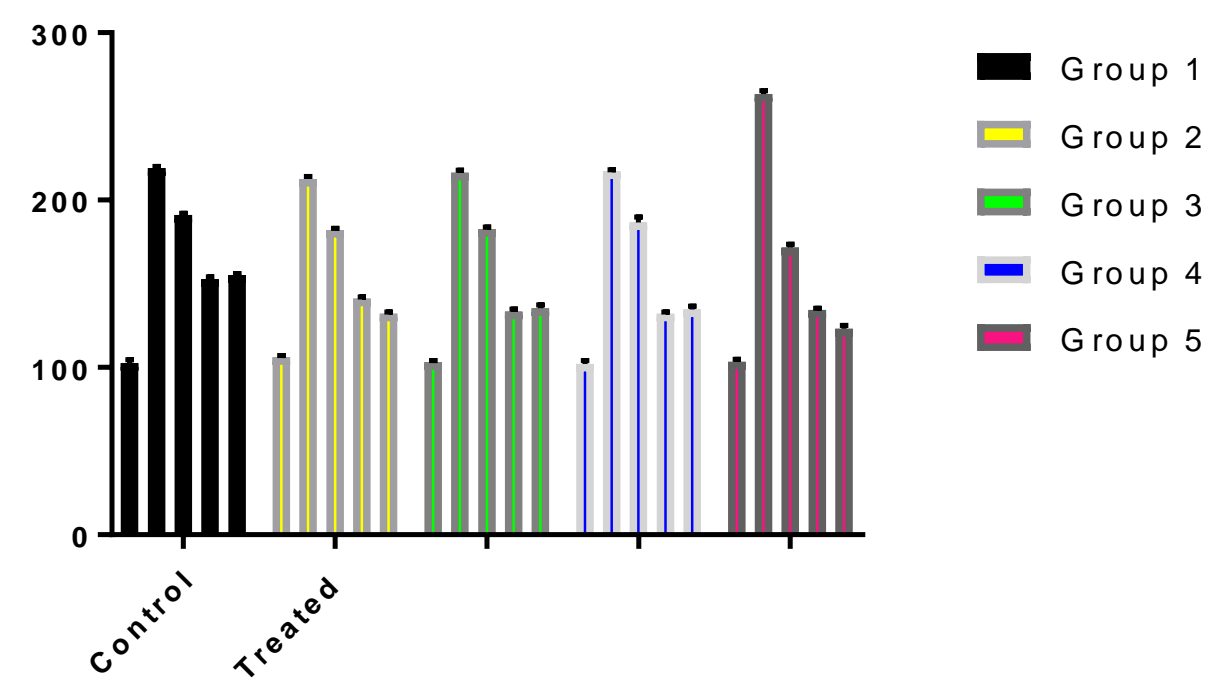

Figure 2: Blood cholesterol level in induced diabetic rabbits triplicate

\section{Discussion}

In Alloxan diabetic hares, the blood glucose levels are raise because of lasting decimation of pancreatic $\beta$ cells. In addition, the serum insulin levels are diminished in Alloxan diabetic bunnies because of devastation of pancreatic $\beta$ cells. The expansion in serum insulin dimensions of diabetic bunnies as saw in the present work demonstrates that some recovery of pancreatic $\beta$ cells has happened with the utilization of compound formula. This recovery of pancreas tonic, which is made out of a few restorative plants, causes a noteworthy decrease in blood glucose levels because of the recovery of pancreatic $\beta$ islet cells. The recovery is for the most part because of essence monothica that contains noteworthy amount of sugar. It has been accounted for that watery concentrates of the plants delivered a critical decrease in the blood glucose levels in the Rabbits, separate acquired from Monothica boxifolia was tried for hostile to diabetic action in hares and was observed to be powerful against Alloxan-actuated diabetes. Different constituents of Pancreas tonic potentiate the activities of Monothica boxifolia. These constituents additionally can decrease blood glucose dimensions of diabetic bunnies yet they have impact on blood glucose dimensions of Alloxan diabetic hares. This is because of truth these plants can lessen blood glucose dimensions of diabetic hares by invigorating the pancreatic $\beta$ islet cells and subsequently expanding the amount of insulin. As Alloxan annihilates pancreatic $\beta$ islet cells, these constituents have impact on diabetic creatures. The information uncovered that pancreas tonic and compound formula have lower glucose impact in hares however they had caused critical blood decrease in blood glucose 
dimensions of Alloxan diabetic hares. These perceptions propose that these mixes perhaps recover the pancreatic beta cells that discharge insulin that is in charge of decrease in blood glucose levels, it may be recommended that the hypoglycemic movement might be available in Monothica boxifolia.

\section{Conclusion:}

All in all, this investigation demonstrates that the Monothica concentrates have noteworthy hypoglycemic movement. It additionally has cancer prevention agent potential for oxidative pressure delivered by diabetes. The dynamic standard (s) in the concentrates may have better execution secluded and filtered structure in therapeutically it additionally for tooth brush and diuretic and furthermore use is creatures and human for foods grown from the ground.

\section{Reference}

Roussel, M. 1998. Handbook on how to control diabetes. South Africa. Hoechst Marion Roussel.

Van de Venter, M., Roux, S., Bungu, L. C., Louw, J., Crouch, N. R., Grace, O. M., ... Folb, P. (2008). Antidiabetic screening and scoring of 11 plants traditionally used in South Africa. Journal of Ethnopharmacology, 119(1), 81-86. doi:10.1016/j.jep.2008.05.031

Vandebroek, I. (2007). Traditional Herbal Medicines for Modern Times Volume: 6. CRC Press, Taylor and Francis Group, 6000 Broken Sound Parkway, NW. Suite 300. Boca Raton, FL. 33487. xii +. 314 (paperback). US\$ 139.95. ISBN: 0-415-334640. Economic Botany, 61(2), 206-206. doi:10.1663/00130001(2007)61[206a:tmfmta]2.0.co;2

Van Huyssteen, M. 2007. Collaborative research with traditional African health practitioners of the Nelson Mandela Metropole; antimicrobial, anticancer activities of five medicinal plants. $\mathrm{PhD}$ thesis. Nelson Mandela Metropolitan University. Port Elizabeth. pp. 1-255.

Tietz, N. W., 1995. Clinical guide to laboratory tests, $3^{\text {rd }}$ Ed., (W. B. Saunders eds. Philadelphia USA, 268. 